University of Nebraska - Lincoln

DigitalCommons@University of Nebraska - Lincoln

\title{
Library E-Resources at Your Doorsteps: A Study Based on INFLIBNET's INFED Access
}

Dr. Sudhi S. Vijayan

University of Kerala, sudhivijayan@gmail.com

Renjith V. R

University of Kerala, renjithliber@gmail.com

Follow this and additional works at: https://digitalcommons.unl.edu/libphilprac

Part of the Library and Information Science Commons

Vijayan, Dr. Sudhi S. and R, Renjith V., "Library E-Resources at Your Doorsteps: A Study Based on INFLIBNET's INFED Access" (2021). Library Philosophy and Practice (e-journal). 5526.

https://digitalcommons.unl.edu/libphilprac/5526 


\title{
Library E-Resources at Your Doorsteps: A Study Based on INFLIBNET's INFED Access
}

\author{
Dr. Sudhi S. Vijayan \\ Assistant Professor \\ Dept. of Library and Information Science \\ University of Kerala, Thiruvananthapuram \\ ORCID: 0000-0002-2228-9031 \\ sudhivijayan@gmail.com \\ V. R. Renjith \\ Reference Assistant \\ Campus Library, Kariavattom Campus, \\ University of Kerala, Thiruvananthapuram, India \\ ORCID: 0000-0002-2389-7338 \\ renjithliber@gmail.com
}

\begin{abstract}
Globally, during the lockdown due to the Covid pandemic, the library services are a challenging one that changed both the publishers' and librarians' outlook, which resulted in the maximum utilization of library electronic resources through remote login. This study aims to analyze the universities in India utilizing e-resources through the INFED facility. It seeks to analyze region-wise, category-wise and state-wise access of INFED by different universities across the country. Data was collected directly from the INFED website. A total of 171 institutions were identified as member institutions in INFED till $1^{\text {st }}$ February 2021.Out of these 171 member institutions, 101 institutions identified as universities were taken for the present study. It is surprising to note that only $10.44 \%$ of the Indian universities are using the INFED facility. The lion's share of universities (89.56\%) is not using the INFED technology. INFED accessing universities were also broken down by region and category wise and it is found that universities in the South (38.61\%) and North (32.67\%) are more accessing than universities in other regions and regarding the category-wise analysis, state universities $(45.54 \%)$ are accessing more. The region-wise university analysis shows that despite the fact that the number of universities is higher in Northern region (336) than Southern region (201), the higher the number of universities joined in INFED is from Southern region (4.03\%). Tamil Nadu (14.85\%) and Karnataka (12.87\%) states have more INFED accessing
\end{abstract}


universities and furthermore these states are located in the Southern zone. The top five institutions in the NIRF ranking are the two universities from the Southern and three universities from the Northern region, including three Central, one Deemed and one State university.

Keywords: INFED, Remote Login, Remote Access, INFLIBNET, Educational Web Portals, Online Educational Resources, India.

\section{Introduction}

The COVID-19 pandemic began as a worldwide health crisis as it spread rapidly across nations, and as part of that the majority of the countries executed lockdown. The recent outbreak of the Covid-19 pandemic has changed the entire world, and as a result, every sector has rehabilitated its service delivery methods during this period. Libraries were also changed in the way of providing services to their users. The 2020 Covid-19 pandemic has had an unprecedented impact on Higher Education (HE) libraries, requiring them to rapidly overhaul their services and accelerating the shift to digital in a short space of time. One of the most significant challenges has been how to provide students and other library users with continued access to resources previously only available in print when libraries have been closed or are operating with restrictions in place that limit access to the physical library space.

Libraries having a significant number of e-resources have made enough opportunities to serve their users even in the lockdown period and after throughout the world. During and after the outbreak of this pandemic disease, libraries worldwide provide access to their e-resources through remote login facilities. Remote login is now widely used by libraries all over the world to facilitate access to scholarly literature. But in India, the studies show that the situation is wretched proper as we know it; like other sectors, libraries worldwide are also facing hard choices around which services to offer and how ranging from minimal restrictions to full closure (Illias, 2020). In the present technological world, information is disseminated to its 
potential users in different formats, especially in digital form. Dr. A.P.J Abdul Kalam, former President of India, said that Digital Libraries are "where the past meets the present and creates a future. Digital library provides equitable access to knowledge to all people, irrespective of place, caste creed, color or economic status. Digital library unites rather than divide. Therefore there is a need of time to develop digital libraries".

\section{About INFED}

Most of the information providers enable access to their e-resource products via IP-based access. IP-based access is an open standard for the authentication of eresource access from subscribing entities by legal users. Although IP-based access for publishers and subscribing organizations is the most appropriate, safe and hassle-free authentication method, it has some limitations. One of the major drawbacks of IPfiltered e-resource access is that users can access e-resources while at the subscribing institution. In an ideal world, a registered person, regardless of their physical location, should be able to access e-resources at any time as long as they have access to the internet. The INFLIBNET Access Management Federation (INFED) has introduced shibboleth, a standard open-source program to authenticate approved users from institutions and provide them with continuous access to e-resources from anywhere, at any time, to address this constraint. Within a federated single sign-on system, shibboleth delivers a method for users to access multiple services. INFED aims to allow users to use a single, institutionally regulated identity to access internal and

external resources effortlessly. INFED will enable e-resources to be accessed by approved users anywhere and eliminate the need to maintain multiple passwords for multiple resources in different domains.

\section{Review of Literature}

Jagdish Arora and Nabi Hasan (2015) explained that the INFLIBNET Centre, as an executing agency for the UGC-INFONET Digital Library Consortium and NLIST projects in India, has taken the responsibility of authenticating users from all 
6,000 colleges since neither these colleges nor their affiliating universities are equipped or have technical capabilities to run their Shibboleth-based authentication mechanism (or say, identity provider). The INFED would host Identity Provider Services that would virtually serve all 6,000 colleges. All 180+ universities that are members of the UGC-INFONET Digital Library Consortium would also be allowed to host and maintain their identity database at the INFED Server. However, universities with technical capabilities, requisite technological know-how and necessary computing and network infrastructure would be encouraged to set up their IDPs as per the technical specifications defined by the INFED. Since the Shibboleth model is designed to run on separate distributed Identity Provider Services located in the participating institutions, necessary changes have been made in software to host multiple Identity Provider Services virtually on servers hosted at the INFED.

Rafique, Ameen and Arshad (2019) explored the evidence-based patterns of ejournal usage, such as the most used and least used databases, at a public-sector university in Pakistan. The frequencies of page views, sessions, session duration, and size of the used data were calculated through SAWMILL software through transaction log analysis. The results revealed that the broad databases of science and engineering were being used more by users than the narrower e-journal databases. Furthermore, the users mostly accessed thee-journal databases from the University's central library and its various academic departments. Early morning hours, working days and the starting of the academic year were found to be the most active timings of e-journal database utilization.

Bhat (2019) attempted to study the comparison between Remote access facilities provided by Allama Iqbal Library using different software's viz., EZproxy and RemoteXs and its impact on the user community at the University. The costeffective cloud-based service model of RemoteXs has enabled the Allama Iqbal Library system to create its digital library portal to reach the target users efficiently. 
The findings showed that users from all categories used e-resources, and the awareness about e-resources encouraged users to use such resources to the maximum.

Sukula and Babbar (2020) described the changing scenario of libraries in the pandemic Covid-19 situation due to the non-contact kind of facilitation to users. Clearly, they stated that technological advances have proven to be a boon for libraries. They highlighted the various perspectives and support systems in academic libraries and how the remote access-based services can be fruitful. They have been deliberated with the example of the JNU library and other significant current challenges and solutions.

Bilawar (2020) briefing about Corona, Covid-19 virus, lockdown period and the compilation of online/live academic/learning programs/activities rendered by different universities, colleges and associations/institutions during the lockdown period, which served as information sources to engage students and teachers/faculties in their teaching, learning and extension processes in India with more emphasis on Library \& Information Science online events. Further, the paper explored the title/topic/theme of the webinar and other online event titles against the different subjects that can be useful for further planning and suggesting of new webinar title and its theme.

\section{Shibboleth and its Components}

Shibboleth system is a standards-based, open-source software system that facilitates single sign-on web-based access to electronic resources across or within organizational boundaries. On the one hand, the Shibboleth system allows institutions to authenticate authorized users using organization's internal identity and access management system, enabling them to access subscription-based electronic resources in a privacy-preserving manner. On the other hand, it allows secure or subscription-based websites to make informed decisions about users who have been appropriately authenticated by their respective institutions and grant access to their e-resources based on their entitlement as specified in the authentication attributes passed on by their institutions during the authentication process. Users may access designated electronic 
resources within the confines of their institute's campuses and off-campus using this technology.

Shibboleth is open source middleware software that enables sites to make informed authorization decisions for individuals and provide subscription-based electronic resource access. Shibboleth uses the campus identification and access control infrastructure to authenticate people and then sends the information to the resource site, allowing the resource provider to decide about a user's authenticity and authorization. For both Identity and Service Providers, Shibboleth-enabled access simplifies the management of identity and access permissions.

Shibboleth consists of the following two primary components:

\section{a) Identity Provider:}

Institutions run the Identity Provider software with a User Database entitled to access subscription-based e-resources or services. Shibboleth leverages the identity and access management system of the organization so that the individual's relationship with the institution can be used to determine the rights of access to subscription-based e-resources or services.

\section{b) Service Provider:}

An e-resource or service-based subscription publisher runs Service Provider software. The Service Provider receives a set of pre-defined attributes from the Identity Provider (IP) and provides the users with access to subscribed eresources or services, depending on the facts received. INFED manages the trusts between all the parties at the INFLIBNET Centre.

\section{Regions in India}

Republic of India is a country in South Asia which is the seventh biggest country by area, the second-most populous country (with over 1.2 billion people), and the most populous democracy in the world. It is surrounded by the Indian Ocean on the south, the Arabian Sea on the southwest, and the Bay of 
Bengal on the southeast. It shares land borderswithPakistan tothe west; China, Nepal, and Bhutan to thenortheast; and Myanmar (Burma) and Bangladesh to the east.

This is a list of unofficial or quasi-official regions of India. There are six regions in India, and they are North, South, West, East, Central and Northeast. On the basis of above regions, the universities in the present study are classified. The Indian Union Territories get representation in their concerned regions. Puducherry formerly known as Pondicherry is a union territory of India included in Tamil Nadu state in southern region, Chandigarh a union territory of India that serves as the capital of the Indian states of Haryana and Punjab and Delhi India's capital territory, is a massive metropolitan area in the country's north and Ladakh in Jammu \& Kashmir are includes in Northern Regions.

\section{Objectives}

The objective of the present study is to trace out the number of universities in India having membership and thereby accessing the INFLIBNET's INFED facility and further the study tries to analyze the number of universities accessing the facility, region-wise, category-wise, state-wise. Finally the study proceeds to identify the universities having membership in INFED and at the same time included in the recent NIRF Ranking databases of MHRD, Govt. of India.

\section{Materials and Methods}

The present study covers the entire data from the INFLIBNET-INFED website regarding the member institutions up to the period as on $1^{\text {st }}$ February 2020. A total of 171 institutions were identified as member institutions in INFED as on the date $1^{\text {st }}$ February 2021. Out of these 171 member institutions, 101 institutions identified as universities were taken for the present study. The details regarding the list of universities were selected from the UGC website, and the region-wise analyses are prepared. The data was entered, and analysis was done with the help of an Excel sheet. The collected data are analyzed using calculations with percentage and ranking. 
Within the study period, there are 101 universities that have accessed the INFED facility. Out of 967 universities across the country, only 101 (10.44\%) universities are using the INFED facility. In other words, the remaining $89.56 \%$ of universities are not accessing the INFED facility. The lion's shares of the universities are still unaware or not taking the initiative in using the INFED facility. These 101 universities are also subjected to further analysis based on their NIRF ranking.

\section{Scope and Limitations}

The study helps to identify the difference in the number of universities in India, region-wise, state-wise, category-wise and finally NIRF ranked with regard to their access and membership in INFED. The study has certain limitations. The most important one is that the fast growth in the INFED members' registration, i.e. more universities is registering day by day. So the study has no control over new execution and upcoming improvements that take place consequently in the INFED website. Those universities who joined up to 1st February 2021 are only considered for the study. Out of the 967 universities, only 101(10.44\%) of them are using the INFED facility remaining 857 (89.56\%) universities are still behind the curtain.

\section{Analysis and Interpretation}

The collected from data from the INFED, UGC, and INFLIBNET websites are consolidated and analyzed under the following headings:

\subsection{List of Universities in India}

As per the list published by UGC as on 31.12.2020, the total number of universities in the country is allocated in four categories in each state and union territories in India. Out of the 967 universities, most of them are State Universities (418, 43.23\%), and subsequently Private Universities (370, 38.26\%). Apart from the above universities, Deemed Universities (125, 12.92\%) and Central Universities (54, 5.58\%) are less in number when compared to State and Private Universities. The highest number of universities is in Rajasthan with 85 and the lowest in Goa with one university (Indian Union Territory) (Table 1). 
Table 1: Total Universities in India - State-wise \& Category-wise

\begin{tabular}{|c|c|c|c|c|c|c|}
\hline \multirow{2}{*}{ State/ Union territories } & \multicolumn{4}{|c|}{ Category } & \multirow{2}{*}{ Total } & \multirow{2}{*}{$\%$} \\
\hline & State & Private & Deemed & Central & & \\
\hline Andhra Pradesh & 23 & 6 & 4 & 3 & 36 & 3.72 \\
\hline Arunachal Pradesh & 0 & 8 & 1 & 1 & 10 & 1.03 \\
\hline Assam & 16 & 6 & 1 & 2 & 25 & 2.59 \\
\hline Bihar & 18 & 7 & 1 & 4 & 30 & 3.10 \\
\hline Chandigarh & 1 & 0 & 1 & 0 & 2 & 0.21 \\
\hline Chhattisgarh & 14 & 12 & 0 & 1 & 27 & 2.79 \\
\hline Delhi & 8 & 0 & 8 & 7 & 23 & 2.38 \\
\hline Goa & 1 & 0 & 0 & 0 & 1 & 0.10 \\
\hline Gujarat & 31 & 41 & 3 & 1 & 76 & 7.86 \\
\hline Haryana & 20 & 24 & 6 & 1 & 51 & 5.27 \\
\hline Himachal Pradesh & 6 & 17 & 0 & 1 & 24 & 2.48 \\
\hline Jammu and Kashmir & 9 & 0 & 0 & 2 & 11 & 1.14 \\
\hline Jharkhand & 11 & 15 & 1 & 1 & 28 & 2.90 \\
\hline Karnataka & 32 & 19 & 14 & 1 & 66 & 6.83 \\
\hline Kerala & 13 & 0 & 3 & 1 & 17 & 1.76 \\
\hline Ladakh & 1 & 0 & 1 & 0 & 2 & 0.21 \\
\hline Madhya Pradesh & 24 & 38 & 1 & 2 & 65 & 6.72 \\
\hline Maharashtra & 24 & 18 & 21 & 1 & 64 & 6.62 \\
\hline Manipur & 3 & 3 & 0 & 3 & 9 & 0.93 \\
\hline Meghalaya & 0 & 8 & 0 & 1 & 9 & 0.93 \\
\hline Mizoram & 0 & 1 & 0 & 1 & 2 & 0.21 \\
\hline Nagaland & 0 & 3 & 0 & 1 & 4 & 0.41 \\
\hline Odisha & 18 & 8 & 3 & 1 & 30 & 3.10 \\
\hline Puducherry & 0 & 0 & 1 & 1 & 2 & 0.21 \\
\hline Punjab & 12 & 15 & 2 & 1 & 30 & 3.10 \\
\hline Rajasthan & 23 & 53 & 8 & 1 & 85 & 8.79 \\
\hline Sikkim & 1 & 4 & 0 & 1 & 6 & 0.62 \\
\hline Tamil Nadu & 22 & 0 & 28 & 2 & 52 & 5.38 \\
\hline Telangana & 17 & 5 & 3 & 3 & 28 & 2.90 \\
\hline Tripura & 1 & 1 & 0 & 1 & 3 & 0.31 \\
\hline Uttar Pradesh & 31 & 29 & 9 & 6 & 75 & 7.76 \\
\hline Uttarakhand & 11 & 18 & 3 & 1 & 33 & 3.41 \\
\hline West Bengal & 27 & 11 & 2 & 1 & 41 & 4.24 \\
\hline Total & 418 & 370 & 125 & 54 & 967 & $100 \%$ \\
\hline$\%$ & 43.23 & 38.26 & 12.93 & 5.58 & 100 & \\
\hline
\end{tabular}

\subsection{Region-wise and Category-wise Distribution of Universities in India}


Table no. 2 reveals the region-wise distribution of universities and their category. Among the 967 universities, North Indian universities ranked first position (34.75\%), followed by South Indian universities (20.79\%) and universities from North East Region are in the last place with only 7.03\%. The universities from the West (14.58\%), East(13.34\%) and Central (9.51\%) are also less in number when compared to North and South regions.

The results show that $43.23 \%$ are State Universities in the category-wise analysis of universities, followed by $38.26 \%$ Private Universities. The Deemed Universities (12.93\%) and the Central Universities (5.58\%) are less in number when compared to State and Private Universities.

Table 2: Region and Category-wise Distribution of Universities in India

\begin{tabular}{|c|c|c|c|c|c|c|c|}
\hline Rank & Region-wise & State & Private & Deemed & Central & $\begin{array}{c}\text { Region } \\
\text { Wise } \\
\text { Total }\end{array}$ & $\begin{array}{c}\text { Region } \\
\text { Wise } \\
\%\end{array}$ \\
\hline 1 & North India & 122 & 156 & 38 & 20 & 336 & 34.75 \\
\hline 2 & South India & 107 & 30 & 53 & 11 & 201 & 20.79 \\
\hline 3 & Western India & 56 & 59 & 24 & 2 & 141 & 14.58 \\
\hline 4 & East India & 74 & 41 & 7 & 7 & 129 & 13.34 \\
\hline 5 & Central India & 38 & 50 & 1 & 3 & 92 & 9.51 \\
\hline 6 & Northeast India & 21 & 34 & 2 & 11 & 68 & 7.03 \\
\hline \multicolumn{2}{|c|}{ Overall Universities Total } & 418 & 370 & 125 & 54 & \multirow{2}{*}{\multicolumn{2}{|c|}{$\begin{array}{c}967 \\
100 \%\end{array}$}} \\
\hline & $\%$ & 43.23 & 38.26 & 12.93 & 5.58 & & \\
\hline
\end{tabular}

9.3 Region and Category-wise Analysis of Universities having INFED Access Facility

Table 3 discloses category-wise and region-wise analysis of universities accessing INFED facility.

Region-wise analysis elucidates that the INFED access facilities is more or less the same among the Southern and Northern region universities, i.e. 39 (38.61) and $33(32.67 \%)$ respectively. But the access from the Western (13.86\%), Eastern(6.93\%), North Eastern (5.94\%) and Central (1.98\%) regions are significantly less compared to the Southern and Northern region. 
Category-wise results reveal that from the 101 INFED accessing universities, the State Universities (45.54\%) contribute a major share in accessing the facility. The Central Universities (20.79\%), Private (14.85\%) and Deemed Universities (18.81\%) are also accessing the INFED facilities, which are significantly less than that of State Universities.

Table 3: Category and Region-wise: Analysis of Universities having INFED Access Facility

\begin{tabular}{|c|c|c|c|c|c|c|}
\hline Region & State & Private & Deemed & Central & Total & $\begin{array}{c}\% \text { based on } \\
\text { access }\end{array}$ \\
\hline South India & 21 & 5 & 11 & 2 & 39 & 38.61 \\
\hline North India & 13 & 6 & 4 & 10 & 33 & 32.67 \\
\hline Western India & 8 & 2 & 4 & 0 & 14 & 13.86 \\
\hline East India & 4 & 1 & 0 & 2 & 7 & 6.93 \\
\hline Northeast India & 0 & 0 & 0 & 6 & 6 & 5.94 \\
\hline Central India & 0 & 1 & 0 & 1 & 2 & 1.98 \\
\hline $\begin{array}{r}\text { Total Universities Accessing } \\
\text { INFED }\end{array}$ & 46 & 15 & 19 & 21 & \multirow[t]{2}{*}{101} & \multirow[t]{2}{*}{$100 \%$} \\
\hline$\%$ Based on Access & 45.54 & 14.85 & 18.81 & 20.79 & & \\
\hline
\end{tabular}

9.4 Region and Category-wise Analysis of Universities having INFED Access Facility Based on Total Universities in India

When compared to the total number of universities in the country (Table 4), the highest number of universities are from the Northern (336), followed by the Southern (201) regions. But in accessing the INFED, it is vice versa, i.e. higher number of universities are from the South (4.03\%) followed by the North $(3.41 \%)$. The INFED access from the West $(1.45 \%)$, East $(0.72 \%)$, Northeast $(0.62 \%)$ and Central regions $(0.21 \%)$ are considerably less.

Category wise analysis of universities accessing INFED discloses that out of 418 State Universities, only 46 State Universities (11\%) are accessing.Likewise out of 370 Private Universities only 15 Universities (4.05\%)make use of the facility.Similarly out of 125 Deemed Universities only 19 Universities (15.20\%)and out of 54 Central Universities only 21 Universities (38.89\%) are the users of INFED facility. 
The total number of universities joined in the INFED is only $10.44 \%$ of all categories of universities, so the INFLIBNET authorities should take necessary action to get out of those who are still behind the curtain.

Table 4: Category and Region-wise Analysis of Universities having INFED Access Facility Based on Total Universities in India

\begin{tabular}{|c|c|c|c|c|c|c|c|}
\hline Region & State & Private & Deemed & Central & Total & $\begin{array}{c}\text { Total } \\
\text { Universities }\end{array}$ & $\begin{array}{c}\% \text { based on } \\
\text { total } \\
\text { Universities }\end{array}$ \\
\hline South India & 21 & 5 & 11 & 2 & 39 & 201 & 4.03 \\
\hline North India & 13 & 6 & 4 & 10 & 33 & 336 & 3.41 \\
\hline Western India & 8 & 2 & 4 & 0 & 14 & 141 & 1.45 \\
\hline East India & 4 & 1 & 0 & 2 & 7 & 129 & 0.72 \\
\hline Northeast India & 0 & 0 & 0 & 6 & 6 & 68 & 0.62 \\
\hline Central India & 0 & 1 & 0 & 1 & 2 & 92 & 0.21 \\
\hline $\begin{array}{l}\text { Total Universities } \\
\text { accessing INFED }\end{array}$ & $\begin{array}{c}46 \\
(11.00)\end{array}$ & $\begin{array}{c}15 \\
(4.05)\end{array}$ & $\begin{array}{c}19 \\
(15.20)\end{array}$ & $\begin{array}{c}21 \\
(38.89)\end{array}$ & 101 & 967 & 10.44 \\
\hline Total Indian Universities & 418 & 370 & 125 & 54 & & & \\
\hline
\end{tabular}

\subsection{Region-wise Analysis of Universities having INFED Access Facility Based on}

\section{Total Universities in India}

Scrutinizing the total region-wise analysis of universities in the country (Table 5) discloses that out of 201 universities from the south, INFED facility is accessed by only $19.40 \%$ (39) of universities in that region. While considering northern universities, it is $9.82 \%$ (33), and western $9.93 \%$ (14). Out of 68 universities from the North Eastern regiononly six universities $(8.82 \%)$ are accessing the facility. Similarly out of 129 universities from the East, only $5.43 \%$ and out of 92 universities from the central region, only $2.17 \%$ are accessing the facilities.

Table 5: Region-wise Analysis of Universities Accessing INFED Facility Based on Total Universities in India

\begin{tabular}{|c|c|c|c|c|c|c|c|}
\hline Region & State & Private & Deemed & Central & Total & $\begin{array}{c}\text { Total } \\
\text { Universities }\end{array}$ & $\begin{array}{c}\text { \% based on Total } \\
\text { Universities } \\
\text { Region-Wise }\end{array}$ \\
\hline South India & 21 & 5 & 11 & 2 & $\mathbf{3 9}$ & $\mathbf{2 0 1}$ & 19.40 \\
\hline North India & 13 & 6 & 4 & 10 & $\mathbf{3 3}$ & $\mathbf{3 3 6}$ & 9.82 \\
\hline Western India & 8 & 2 & 4 & 0 & $\mathbf{1 4}$ & $\mathbf{1 4 1}$ & 9.93 \\
\hline East India & 4 & 1 & 0 & 2 & $\mathbf{7}$ & $\mathbf{1 2 9}$ & 5.43 \\
\hline
\end{tabular}




\begin{tabular}{|c|c|c|c|c|c|c|c|}
\hline Northeast India & 0 & 0 & 0 & 6 & $\mathbf{6}$ & $\mathbf{6 8}$ & 8.82 \\
\hline Central India & 0 & 1 & 0 & 1 & $\mathbf{2}$ & $\mathbf{9 2}$ & 2.17 \\
\hline $\begin{array}{r}\text { Total } \\
\text { Universities }\end{array}$ & $\mathbf{4 6}$ & $\mathbf{1 5}$ & $\mathbf{1 9}$ & $\mathbf{2 1}$ & $\mathbf{1 0 1}$ & $\mathbf{9 6 7}$ & \\
accessing INFED & & & & \\
\hline
\end{tabular}

9.6 State-wise Analysis of Universities Accessing INFED Facility

Analyzing the State Universities that participate in INFED show that nine State Universities from Tamil Nadu have maximum participation. At the same time, State Universities from Himachal Pradesh, Jammu \& Kashmir, Uttarakhand, Assam, Manipur, Sikkim, Tripura, Chhattisgarh, Madhya Pradesh and Jharkhand are not taking part in INFED. Examining the Private Universities that join in INFED shows that four Private Universities from Karnataka have maximum participation. At the same time, Private Universities from Telangana, Himachal Pradesh, Punjab, Maharashtra, Arunachal Pradesh, Assam, Manipur, Meghalaya, Mizoram, Nagaland, Sikkim, Tripura, Madhya Pradesh, Jharkhand, Odisha and Bihar states yet to participate in INFED.

Evaluating the Deemed universities that participate in INFED shows that five Deemed Universities from Tamil Nadu have maximum participation. At the same time, State Universities from Kerala, Telangana, Delhi, Uttar Pradesh, Uttarakhand, Gujarat, Arunachal Pradesh, Assam, Chhattisgarh, Madhya Pradesh, Jharkhand, Odisha, West Bengal and Bihar states yet to participate in INFED. Scrutinizing the Central Universities that take part in INFED appears that three Central Universities from Delhi have the most extreme participation. At the same time, Central Universities from Andhra Pradesh, Karnataka, Telangana, Himachal Pradesh, Uttarakhand, Gujarat, Maharashtra, Meghalaya, Mizoram, Chhattisgarh, Jharkhand and West Bengal states yet to participate in INFED.

A total number of 101 universities are using the INFED facilities from the following 25 states in India. The lion's share of INFED accessing universities is from Tamil Nadu and Karnataka; both the states are from the country's southern region. 
Simultaneously, the number of universities from the North East and Central region is less in number (Table 6 \& 7).

Table 6: State-wise Analysis of Universities Accessing INFED Facility

\begin{tabular}{|c|l|r|r|}
\hline Sl. No. & \multicolumn{1}{|c|}{ State } & Total Universities & \% \\
\hline 1 & Tamil Nadu & 15 & 14.85 \\
\hline 2 & Karnataka & 13 & 12.87 \\
\hline 3 & Haryana & 8 & 7.92 \\
\hline 4 & Andhra Pradesh. & 6 & 5.94 \\
\hline 5 & Delhi & 6 & 5.94 \\
\hline 6 & Gujarat & 6 & 5.94 \\
\hline 7 & Maharashtra & 6 & 5.94 \\
\hline 8 & Rajasthan & 6 & 5.94 \\
\hline 9 & Kerala & 5 & 4.95 \\
\hline 10 & Punjab & 5 & 4.95 \\
\hline 11 & Uttar Pradesh & 5 & 4.95 \\
\hline 12 & West Bengal & 3 & 2.97 \\
\hline 13 & Bihar & 2 & 1.98 \\
\hline 14 & Goa & 2 & 1.98 \\
\hline 15 & Jammu & 2 & 1.98 \\
\hline 16 & Odisha & 2 & 1.98 \\
\hline 17 & Arunachal Pradesh & 1 & 0.99 \\
\hline 18 & Assam & 1 & 0.99 \\
\hline 19 & Chhattisgarh & 1 & 0.99 \\
\hline 20 & Madhya Pradesh & 1 & 0.99 \\
\hline 21 & Manipur & 1 & 0.99 \\
\hline 22 & Nagaland & 1 & 0.99 \\
\hline 23 & Sikkim & 1 & 0.99 \\
\hline 24 & Tripura & 1 & 0.99 \\
\hline 25 & Uttarakhand & 1 & 0.99 \\
\hline & & & \\
\hline
\end{tabular}

Table 7: State-wise, Category-wise and Region-wise: Analysis of Universities Accessing INFED Facility

\begin{tabular}{|c|c|c|c|c|c|c|c|}
\hline SI. & \multirow[b]{2}{*}{ State } & \multirow{2}{*}{$\begin{array}{c}\text { Region } \\
\text { (Overall } \\
\text { Universities) }\end{array}$} & \multicolumn{4}{|c|}{ University Category } & \multirow[b]{2}{*}{$\begin{array}{c}\text { Total } \\
\text { Access } \\
\end{array}$} \\
\hline No. & & & State & Private & Deemed & Central & \\
\hline 1 & Andhra Pradesh & \multirow{5}{*}{$\begin{array}{l}\text { South } \\
\text { (201) }\end{array}$} & 3 & 1 & 2 & 0 & 6 \\
\hline 2 & Karnataka & & 5 & 4 & 4 & 0 & 13 \\
\hline 3 & Kerala & & 4 & 0 & 0 & 1 & 5 \\
\hline 4 & Tamil Nadu & & 9 & 0 & 5 & 1 & 15 \\
\hline 5 & Telangana & & 0 & 0 & 0 & 0 & 0 \\
\hline & & Total & 21 & 5 & 11 & 2 & $39(19.40)$ \\
\hline
\end{tabular}




\begin{tabular}{|c|c|c|c|c|c|c|c|}
\hline 6 & Delhi & \multirow{8}{*}{$\begin{array}{l}\text { North } \\
\mathbf{( 3 3 6 )}\end{array}$} & 3 & 0 & 0 & 3 & 6 \\
\hline 7 & Haryana & & 5 & 1 & 1 & 1 & 8 \\
\hline 8 & Himachal Pradesh & & 0 & 0 & 0 & 0 & 0 \\
\hline 9 & Punjab & & 2 & 0 & 2 & 1 & 5 \\
\hline 10 & Jammu \&Kashmir & & 0 & 0 & 0 & 2 & 2 \\
\hline 11 & Rajasthan & & 2 & 2 & 1 & 1 & 6 \\
\hline 12 & Uttar Pradesh & & 1 & 2 & 0 & 2 & 5 \\
\hline 13 & Uttarakhand & & 0 & 1 & 0 & 0 & 1 \\
\hline & & Total & 13 & 6 & 4 & $\mathbf{1 0}$ & $33(9.82)$ \\
\hline 14 & Goa & \multirow{3}{*}{$\begin{array}{l}\text { West } \\
(\mathbf{1 4 1})\end{array}$} & 1 & 0 & 1 & 0 & 2 \\
\hline 15 & Gujarat & & 4 & 2 & 0 & 0 & 6 \\
\hline 16 & Maharashtra & & 3 & 0 & 3 & 0 & 6 \\
\hline & & Total & 8 & 2 & 4 & $\mathbf{0}$ & $14(9.93)$ \\
\hline 17 & $\begin{array}{l}\text { Arunachal } \\
\text { Pradesh }\end{array}$ & \multirow{8}{*}{$\begin{array}{l}\text { North East } \\
\quad(\mathbf{6 8})\end{array}$} & 0 & 0 & 0 & 1 & 1 \\
\hline 18 & Assam & & 0 & 0 & 0 & 1 & 1 \\
\hline 19 & Manipur & & 0 & 0 & 0 & 1 & 1 \\
\hline 20 & Meghalaya & & 0 & 0 & 0 & 0 & 0 \\
\hline 21 & Mizoram & & 0 & 0 & 0 & 0 & 0 \\
\hline 22 & Nagaland & & 0 & 0 & 0 & 1 & 1 \\
\hline 23 & Sikkim & & 0 & 0 & 0 & 1 & 1 \\
\hline 24 & Tripura & & 0 & 0 & 0 & 1 & 1 \\
\hline & & Total & $\mathbf{0}$ & $\mathbf{0}$ & $\mathbf{0}$ & 6 & $6(8.82)$ \\
\hline 25 & Chhattisgarh & \multirow{2}{*}{$\begin{array}{c}\text { Central } \\
\text { (92) }\end{array}$} & 0 & 1 & 0 & 0 & 1 \\
\hline 26 & Madhya Pradesh & & 0 & 0 & 0 & 1 & 1 \\
\hline & & Total & $\mathbf{0}$ & 1 & $\mathbf{0}$ & 1 & $2(2.17)$ \\
\hline 27 & Jharkhand & \multirow{4}{*}{$\begin{array}{l}\text { East } \\
\text { (129) }\end{array}$} & 0 & 0 & 0 & 0 & 0 \\
\hline 28 & Odisha & & 1 & 0 & 0 & 1 & 2 \\
\hline 29 & West Bengal & & 2 & 1 & 0 & 0 & 3 \\
\hline 30 & Bihar & & 1 & 0 & 0 & 1 & 2 \\
\hline \multicolumn{3}{|r|}{ Total } & 4 & 1 & $\mathbf{0}$ & 2 & $7(5.43)$ \\
\hline & & Grand Total (967) & 46 & 15 & 19 & 21 & 101 \\
\hline & & $\%$ & 11.00 & 4.05 & 15.20 & 38.89 & \\
\hline
\end{tabular}

\subsection{NIRF Ranked Universities Accessing INFED Facility}

Ranking of all higher education institutions in India based on their performance is a methodology adopted by the Ministry of Human Resource Development (MHRD), Govt. of India. It is done by the National Institutional Ranking Framework (NIRF). They released their most recent ranking results on $11^{\text {th }}$ June 2020 . There are separate rankings for different institutions depending on their areas of operation like Universities and Colleges, Engineering institutions, Management institutions, Pharmacy institutions and Architecture institutions. The ranking (university-wise) and 
their respective overall ranking in NIRF are taken in the present study for comparison.

Out of the 101 INFED accessing universities, only 30 universities are included in the recent NIRF ranking database. The University-wise NIRF ranking discloses that 4 Central Universities, 9 Deemed Universities, 16 State Universities and 1 Private University is taking part in the facility.

The region-wise analysis exposes that 10 universities are from North, 16 from South and 4 from the Western region and it is also seen that no university having access to INFED from the East, Northeast and Central India region is included in the NIRF ranking database.

A state-by-state survey reported the number of universities having INFED access facility in each state and also included in the NIRF ranking. The top ten NIRF ranking universities in both universities and overall ranking framework of MHRD shows that Karnataka state in the first position, followed by Delhi and Uttar Pradesh in second and third place respectively.

Table 8: NIRF Ranking2020

\begin{tabular}{|c|c|c|c|c|c|}
\hline University & State & Region & Type & $\begin{array}{c}\text { NIRF } \\
\text { Ranking } \\
\text { (University-wise) }\end{array}$ & $\begin{array}{l}\text { Overall } \\
\text { Ranking }\end{array}$ \\
\hline Indian Institute of Science & Karnataka & South & Deemed & 1 & 2 \\
\hline Jawaharlal Nehru University & Delhi & North & Central & 2 & 8 \\
\hline Banaras Hindu University & Uttar Pradesh & North & Central & 3 & 10 \\
\hline University of Delhi & Delhi & North & Central & 11 & 18 \\
\hline Anna University & Tamil Nadu & South & State & 12 & 20 \\
\hline Bharathiar University & Tamil Nadu & South & State & 13 & 21 \\
\hline BITS Pilani & Rajasthan & North & Deemed & 15 & 27 \\
\hline $\begin{array}{l}\text { Institute of Chemical } \\
\text { Technology (ICT), Mumbai }\end{array}$ & Maharashtra & West & Deemed & 18 & 34 \\
\hline $\begin{array}{l}\text { Mahatma Gandhi University, } \\
\text { Kerala }\end{array}$ & Kerala & South & State & 30 & 49 \\
\hline $\begin{array}{l}\text { Thapar Institute of Engineering } \\
\& \text { Technology }\end{array}$ & Punjab & North & Deemed & 31 & 51 \\
\hline
\end{tabular}




\begin{tabular}{|c|c|c|c|c|c|}
\hline $\begin{array}{l}\text { JSS Academy of Higher } \\
\text { Education \& Research }\end{array}$ & Karnataka & South & Deemed & 33 & 54 \\
\hline Alagappa University & Tamil Nadu & South & State & 36 & 64 \\
\hline $\begin{array}{l}\text { Sri Venkateswara University, } \\
\text { Tirupati }\end{array}$ & AndhraPradesh & South & State & 38 & 68 \\
\hline Gujarat University & Gujarat & West & State & 44 & 60 \\
\hline Delhi Technological University & Delhi & North & State & 45 & 62 \\
\hline GurunanakDev University & Punjab & North & State & 51 & 88 \\
\hline Bharathidasan University & Tamil Nadu & South & State & 53 & 77 \\
\hline University of Calicut & Kerala & South & State & 54 & 76 \\
\hline Shiv Nadar University & Uttar Pradesh & North & Private & 56 & 82 \\
\hline Madurai Kamaraj University & Tamil Nadu & South & State & 60 & 84 \\
\hline $\begin{array}{l}\text { Cochin University of Science } \\
\text { and Technology(CUSAT) }\end{array}$ & Kerala & South & State & 62 & 89 \\
\hline BharatiVidyapeeth & Maharashtra & West & Deemed & 63 & 98 \\
\hline Kuvempu University, & Karnataka & South & State & 73 & - \\
\hline $\begin{array}{ll}\text { International Institute } & \text { of } \\
\text { Information Technology } & \end{array}$ & Karnataka & South & Deemed & 78 & - \\
\hline Goa University & Goa & West & State & 81 & - \\
\hline Periyar University & Tamil Nadu & South & State & 83 & - \\
\hline Central University of Punjab & Punjab & North & Central & 87 & - \\
\hline Gandhigram Rural Institute & Tamil Nadu & South & Deemed & 91 & - \\
\hline Kurukshetra University, & Haryana & North & State & 99 & - \\
\hline $\begin{array}{l}\text { Vignan's Foundation for Science, } \\
\text { Technology and Research }\end{array}$ & $\begin{array}{l}\text { Andhra } \\
\text { Pradesh }\end{array}$ & South & Deemed & 100 & - \\
\hline
\end{tabular}

\section{Conclusion}

Emerging technologies require sound leadership and critical thought, which helps to change the technologies at a breathtaking speed, especially in the digital world. The present technologies make revolutionary modification in the services provided by the libraries day by day. The remote login access to e-resources is the best practice of libraries because it offers an opportunity for the best use of the electronic information resources and provides easy access to multiple resources subscribed by the library through its interface from anywhere. Anytime access to the e-resources is now 
implemented by many libraries with the help of INFED. It is a revolutionary transformation in the field of library science profession. We can say that universal access to e-resources from anywhere change users' concept, which maximizes the utilization of the e-resources. The non-awareness about the newly emerging technologies among the users is the main drawback for the under utilization of these types of services. Proper awareness programmes through online mode is the only remedy to overcome these problems in the present technological world. E-resources awareness programmes conducted at regular intervals in the higher education institutions will give a clear cut idea about the benefits, and at the same time will lead to comprehensive marketing and optimum utilization of e-resources.

The Indian higher education system comprises of more than 50,000 institutions in India. INFED can play a crucial role in increasing our country's research output by providing potential researchers with access to scholarly e-resources at anytime, anywhere. Most research institutions do not offer off-campus access to their subscribed resources due to multiple obstacles such as lack of funding and limited technical expertise. By joining INFED, the institutions may, at any time, obtain most of the eresources beyond the boundary of the institutions. The concept and design of federated access with worldwide deployment are in progress. Currently, 171 institutions are

availing INFED facilities. It shows the importance of training/ awareness programmes to be conducted in various institutions throughout the country.

\section{References}

Arora , J., \& Hasan, N. (2015). INFLIBNET's New Initiative in India - INFED (INFLIBNET Access Management Federation). SLA Asian Chapter Newsletter, 11(1), 7-10.

Bhat, I. H. (2019). Remote access (Off-Campus access) to e-resources via EZproxy and RemoteXs facilities: A case study of Allama Iqbal Library system, University of Kashmir. IP Indian Journal of Library Science and Information Technology, 4(1), 25-30. 
Bilawar, P. B. (2020). Lockdown Period and Information Sources. International Journal of Engineering Research and Management (IJERM), 7(6), 7-16.

França, A. (2021). Transforming library collections in a pandemic: The perspective from Edge Hill University. Insights, 34(1).

Illias, S. (2020, August). Information Communication Technologies (ICTs) and Libraries: Importance of Remote Login to Library E-resources at the time of COVID-19 outbreaks. ILIS Newsletter, 2, pp. 14-15.

INFED. (n.d.). INFLIBNET. Retrieved February 6, 2021, from http://infed.inflibnet.ac.in/

NIRF Ranking. (n.d.). Retrieved February 19, 2021, from MHRD: https://www.nirfindia.org/2020/OverallRanking.html

Patel , Y., \& Arora, J. (2011). Technical Implementation of Shibboleth-based Access Management for the NLIST Programme. In R. M.S, O. D.C., \& S. N.K. (Eds.), Benchmarks in ICT Applications in LIS Practices : Essays in Honour of Dr. P.K. Gupta (pp. 1-12). Scientific.

R, G., Nikam, K., M, G. R., \& Mudkavi, V. Y. (2009). Web Log Analysis of E-Journal Usage and Scholarly Communication: A Case Study of E-Journal (Full-Text) Download Patterns of NAL Scientists and Engineers. 15(4), 201-232.

Rafique, A., Ameen, K., \& Arshad , A. (2019). Use patterns of e-journals among the science community: a transaction log analysis. The Electronic Library, 37(4), 740-759. 